\title{
Growth, yield, nutrients uptake and anatomical properties of direct seeding and transplanting maize (Zea mays L.) plants under arbuscular mycorrhizal fungi and water stress
}

\author{
Saeed Rezazadeh, Mohammadnabi Ilkaee, Fayaz Aghayari, Farzad Paknejad, Mehdi Rezaee \\ Department of Agronomy and Plant Breeding, Karaj Branch, Islamic Azad University, Karaj, Iran
}

\begin{abstract}
The management of cultivation technology and fertilizer application may adjust adverse effects of abiotic stresses such as water deficit on agricultural products. Therefore, a field experiment was carried out on growth, yield, nutrient uptake and anatomical properties of maize under three water regimes (well-watered, moderate stress and severe stress as $25 \%, 50 \%$ and $75 \%$ soil moisture depletion), two cultivations methods (direct seeding and transplanting), and two Arbuscular Mycorrhizal Fungi (AMF) levels (inoculated with Glomus mosae and uninoculated). The results showed that in plants under moderate water stress, the AMF inoculation percent was significantly higher than those under well-watered and sever stress condition. Inoculation percent in direct seeding was lower than transplanting. Transplanting plants had higher biological and kernel yield compared to direct seeding plants. Water stress reduced the total chlorophyll (Chl) content. Transplanting had greater $\mathrm{Chl}$ content in comparison with direct seeding. In all irrigation regimes, transplanting significantly increased $\mathrm{N}$ content. In direct seeding, the highest $\mathrm{P}$ content was observed in moderate stress and uninoculated plants. Stomatal density increased under water stress, but stomatal size decreased. Plants under severe water stress showed increased stomatal density compared with well waterbed conditions. In addition, severe water stress enhanced the UCT compared
\end{abstract}

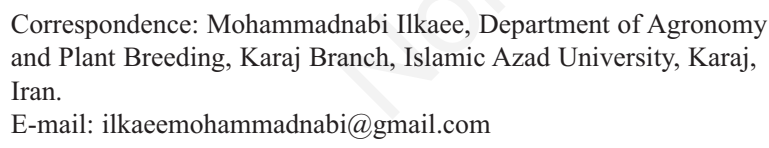

This article is distributed under the terms of the Creative Commons Attribution Noncommercial License (by-nc 4.0) which permits any noncommercial use, distribution, and reproduction in any medium, provided the original author(s) and source are credited. to well-watered condition. This study suggests the use of transplanting with AMF application to cope with the adverse effects of severe water stress on maize.

\section{Introduction}

The undesirable effects of climate changes such as drought have been increasing recently. ${ }^{1}$ The quality and quantity of plants significantly reduced under drought conditions. Plants develop various mechanisms to cope with drought stress such as morphological acclimatization, osmotic adaptation, optimization of water resources, advancement of antioxidant system, improvement of root system, diminishment of growth and photosynthesis rate, and anatomical adaptations, which all purposed to optimize water application. ${ }^{1-3}$ Plants use intrinsic and extrinsic protective systems against environmental stresses. In extrinsic way, the plants attempt to make a corporation with favorable microorganisms presented in the rhizosphere to quench the stress effects. Mycorrhizal fungi as a useful microorganism in the soil can establish this type of symbiosis with most plants. ${ }^{4,5}$ In this association, the plant obtains water and mineral nutrients and, in turn, Arbuscular Mycorrhizal Fungi (AMF) acquire photo-assimilates from the host plant to complete its lifecycle. Thus, AMF plants are more able to uptake nutrients and tolerance against biotic and abiotic stresses. ${ }^{5}$

In agricultural systems, transplanting or replanting is applied as an effective technique by moving a plant from one location to another. Transplanted plants raised under greenhouse or nursery condition, then replanting it in another, usually outdoor, growing location. ${ }^{6}$ Transplanting protects the plants from environmental problems like pests and diseases in the susceptible stage of plant life, i.e., the initial stage of plant growth especially germination. The growth stage of transplanting and the environmental conditions such as the temperature, moisture, and rhizosphere conditions are the main factor in transplanting. ${ }^{6}$

Recently, the excessive use of chemical fertilizers in agriculture systems has accelerated the environmental challenges and concerns globally. In other words, the agricultural approach has globally focused on sustainable agricultural practices and the management strategies such as the application of bio-fertilizers to decrease environmental threats. In this regard, bio-fertilizers beneficially mitigate the unfavorable effects of drought by facilitating the nutrient uptake via root systems, which result in the improvement of plant growth. Previous studies have shown AMF symbiosis alleviates the adverse effects of drought, making the host plant more tolerant to stress. ${ }^{4-8}$ On the other hand, transplanting is the cultivation method to improve the yield of crops. However, a few studies have shown the advantages of transplanting relative to 
direct seeding in different plants, ${ }^{9}$ and there is no published work on transplanting and direct seeding of maize inoculated with AMF under drought stress condition. Therefore, the purposes of the present study were to assess the effects of water stress, AMF inoculation, and cultivation method (transplanting and direct seeding) on plant yield and growth, plant nutrients, and leaf anatomical properties of maize.

\section{Materials and Methods}

\section{Soil and climate of experimental site}

The present study was carried out in the research farm of

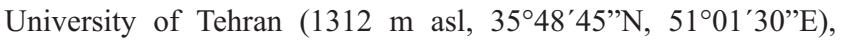
Karaj, Iran. At the beginning of the experiment to measure soil physical and chemical properties, the samples of the surface $(0-$ $30 \mathrm{~cm}$ ) were collected, air-dried, and passed through a 2-mm sieve (Table 1). During the study period, mean maximum temperature fluctuated from $17.3^{\circ} \mathrm{C}$ to $28.2^{\circ} \mathrm{C}$; whereas; mean minimum temperature varied from $2.6^{\circ} \mathrm{C}$ to $15.4^{\circ} \mathrm{C}$. The highest precipitation occurred in March (43.2 mm) and April (39.1 mm) (Figure 1).

\section{Experimental design and treatments}

A factorial experiment was conducted in a randomized complete block design (RCBD) with three replications. Water stress was applied in three levels as well watered (25\% soil moisture depletion), moderate water stress (50\% soil moisture depletion), and severe water stress (75\% soil moisture depletion). AMF inoculation was used in two levels as inoculated with Glomus mosae and uninoculated conditions (control). Cultivation method was selected as direct seeding and transplanting. The presented data were collected in 2017 and 2018.

Maize seeds (SC704) were purchased from Pakan-Bazar Company, Isfahan, Iran. The seeds were surface-sterilized in $10 \%$ (v/v) $\mathrm{H}_{2} \mathrm{O}_{2}$ for $15 \mathrm{~min}$, and they were subsequently washed with deionized water. Uniform seeds were cultivated after germination on moist filter paper at $25^{\circ} \mathrm{C}$ for $36-48$ hours. In this regard, we used two different cultivation methods (direct seeding and transplanting). For transplanting, the seeds were cultivated in the greenhouse of University of Tehran, Karaj, using a culture media including cocopeat and perlite (1:1) for 14 days. After that, the seedlings were transplanted to the open field (Research farm of University of Tehran) on May 25.

\section{AMF inoculum}

The inoculum of G. mosae was provided from Soil Biology Research Division, the Institute of Soil and Water Research, Tehran, Iran, originally produced on sorghum rhizosphere. The inoculum used in the present study contained spores, hyphae, inoculated root segments of sorghum, and sand. The mixture consisted of 120 spores per gram of soil. Five grams of fresh AMF inoculum per plant were used at the time of transplanting.

\section{Moisture treatments application}

All plots were uniformly irrigated after transplanting. To adapt the plants at new environment, the second and third irrigations were applied according to $25 \%$ moisture depletion. The water stress treatments were exerted after the third irrigation according to the depletion of soil water. Irrigation regimes were used by the weighing method, through repeated soil sampling from the depth of root development in the middle of experimental plots. Electric pump and tape were applied in the drip irrigation method. The crop water demand (Ig) was measured according to equation (1) (Sánchez et al. 2011). ${ }^{10}$

$$
I g=\frac{(\Theta f c-\Theta p w p) \times t \times \rho \times D \times A 100}{E a}
$$

where $\theta \mathrm{fc}$ is the soil moisture content at field capacity, $\theta$ pwp is the soil moisture content at wilting point, $t$ is the soil moisture depletion content, $\rho$ is the soil bulk density, $\mathrm{D}$ is the depth of root development, $\mathrm{A}$ is plot area, and $\mathrm{Ea}$ is irrigation water efficiency, which was examined as an average of $90 \% .^{10}$

\section{Mycorrhizal colonization}

To colonize the AMF, 1-cm segments of root samples were provided and combined thoroughly. A sub-sample of $0.5 \mathrm{~g}$ was cleared with $10 \%(\mathrm{w} / \mathrm{v}) \mathrm{KOH}$ at $90{ }^{\circ} \mathrm{C}$ for $120 \mathrm{~min}$, and then stained with trypan blue. Polyvinyl alcohol-lactic acid glycerol (PVLC) was applied to mount the stained roots section on slides, and the arbuscule, vesicule and hyphae in the root were investigated by a light microscope (40x). The mycorrhizal colonization was measured using the MYCOCALC program. ${ }^{11}$

\section{Pigment content assay}

To measure chlorophyll content, $200 \mathrm{mg}$ of fresh leaf samples were homogenized in $8 \mathrm{~mL}$ acetone $(80 \%)$, and homogenates were centrifuged at $4{ }^{\circ} \mathrm{C}$ for $15 \mathrm{~min}(3000 \mathrm{rpm})$. Supernatants were used for analyzing pigments at 645,663 , and $470 \mathrm{~nm} .^{12}$

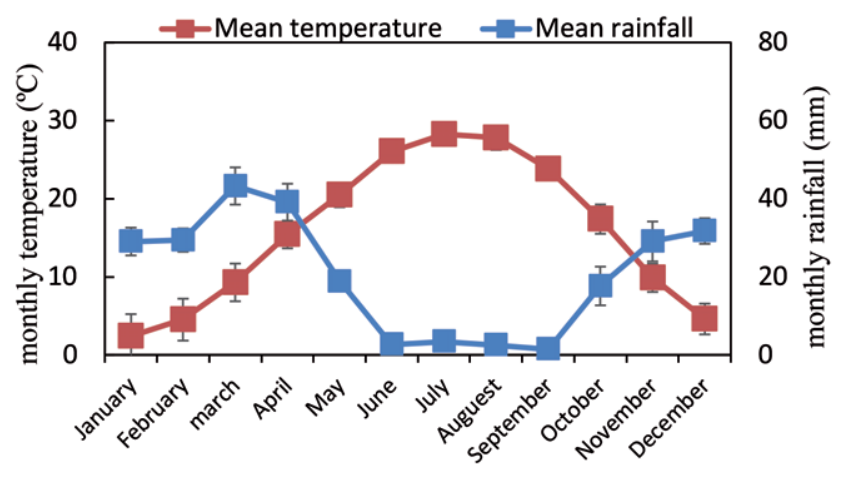

Figure 1. The climate conditions of Karaj during 2018 (National Meteorological organization, Iran).

Table 1. Physical and chemical properties of experimental field soil.

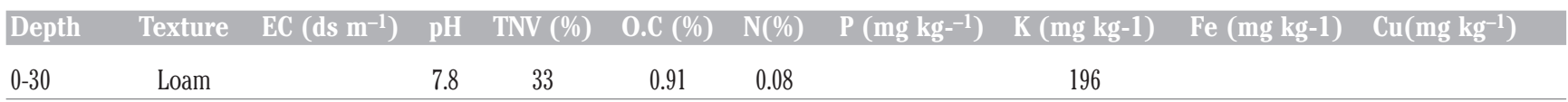




\section{Nutrients concentration}

Nutrient $(\mathrm{N})$ content in the plant leaf was measured at the end of growing season. Kjeldahl method was used to measure $\mathrm{N}$ content using a Kjeldahl equipment (device model of V40). ${ }^{13}$ To calculate leaf phosphorous $(\mathrm{P})$ content, the extract was obtained from the dissolution of plant ash in hydrochloric acid. Vanadium phosphomolybdate colorimetric method was used to measure P content via spectrophotometer apparatus (Vis 2100 model) at $420 \mathrm{~nm} .{ }^{13}$ Potassium (K) was measured using flame photometer based on its standard curve. ${ }^{13}$

\section{Anatomical analyses}

To investigate anatomical features (stomatal density and size), dry leaf samples were coated by gold in vacuum coating unit (SG 110, Iran) based on Khosropour et al. (2019). ${ }^{14}$ After that, Scanning Electron Microscopy (SEM, SU 3500, Hitachi, Japan) were applied to observe the changes.

\section{Statistical analysis}

All data were analyzed statistically by analysis of variance using the software SAS version 9.3 (Cary, NC: SAS Institute Inc., 2011). The means separated using the Duncan test at $\mathrm{P}<0.05$ level.

\section{Results}

\section{Mycorrhizal colonization}

The root colonization was significantly influenced by water stress, AMF inoculation and the interaction of water stress and AMF inoculation (Table 2, $\mathrm{P} \leq 0.01$ ). In plants under moderate water stress, the AMF inoculation percent was significantly higher than those under well-watered and severe stress conditions (Table
$2, \mathrm{P} \leq 0.01)$. In direct seeding and transplanting, intraracial hyphae, arbuscules and vesicles were detected in the roots of all inoculated plants, ranging from $45.6 \%$ to $81.6 \%$ (Table $2, \mathrm{P} \leq 0.01$ ). AMF colonization was not observed in the uninoculated plants (Table 2).

\section{Biological and kernel yield}

Biological yield of maize was significantly affected by the water stress, cultivation method, AMF inoculation, and the interaction of water stress and cultivation method (Table 2, $\mathrm{P} \leq 0.01$ ). Water stress reduced the biological yield of maize (Table 2). Under all irrigation regimes, biological yield of transplanting was higher than that in direct seeding (Table 2). AMF inoculation increased the biological yield of maize. In transplanting plants inoculated with AMF, biological yield increased by $16 \%$ compared to wellwatered condition. Kernel yield was significantly affected by water stress, cultivation method, AMF inoculation, and the interaction of water stress and $\mathrm{AMF}$ inoculation (Table 2, $\mathrm{P} \leq 0.01$ ). In transplanting plants under moderate stress, AMF inoculation improved kernel yield by $10 \%$ in comparison with no AMF inoculation.

\section{Chlorophyll (Chl) contents}

The total $\mathrm{Chl}$ and $\mathrm{Chl} \mathrm{a} / \mathrm{b}$ ratio were influenced by water stress and cultivation method (Table $2, \mathrm{P} \leq 0.01$ ). Under severe water stress and AMF application, transplanting had higher total Chl content $(1.1 \mathrm{mg} / \mathrm{g} \mathrm{FW})$ compared with direct seeding $(0.7 \mathrm{mg} / \mathrm{gr} \mathrm{FW})$ (Table 2). $\mathrm{Chl} \mathrm{a} / \mathrm{b}$ ratio decreased by increasing the water stress rate (Table 2). In direct seeding plants with AMF application, Chl $\mathrm{a} / \mathrm{b}$ ratio in moderate stress $(2.98 \pm 0.11)$ was higher than that in well-watered condition (2.36 \pm 0.08$)$ and severe stress $(2.83 \pm 0.10)$.

Table 2. Effect of Glomus mosae on colonization, plant yield and chlorophyll contents in direct seeding and transplanting maize under water stress.

\begin{tabular}{|c|c|c|c|c|c|c|c|}
\hline Water stress & Uultivation method & Inoculation & Colonization (\%) & $\begin{array}{l}\text { Biological yield } \\
\text { (ton/ha) }\end{array}$ & $\begin{array}{l}\text { Kernel yield } \\
\text { (ton/ha) }\end{array}$ & $\begin{array}{c}\text { Total chl. } \\
\text { (mg/g) }\end{array}$ & chl. a/b ratio \\
\hline Well water condition & $\begin{array}{l}\text { Direct-seeding } \\
\text { Transplanting }\end{array}$ & $\begin{array}{l}+ \\
- \\
+ \\
-\end{array}$ & $\begin{array}{c}63.3 \pm 2.8 \mathrm{~b} \\
0.0 \pm 0.0 \mathrm{e} \\
65 \pm 2.7 \mathrm{~b} \\
0.0 \pm 0.0 \mathrm{e}\end{array}$ & $\begin{array}{c}12.53 \pm 0.13 \mathrm{~d} \\
12.00 \pm 0.11 \mathrm{e} \\
14.10 \pm 0.32 \mathrm{a} \\
13.76 \pm 0.18 \mathrm{bc}\end{array}$ & $\begin{array}{c}5.93 \pm 0.15 \mathrm{~b}-\mathrm{d} \\
6.06 \pm 0.12 \mathrm{~b}-\mathrm{d} \\
6.43 \pm 0.25 \mathrm{a} \\
6.20 \pm 0.22 \mathrm{ab}\end{array}$ & $\begin{array}{c}1.39 \pm 0.11 \mathrm{ab} \\
1.35 \pm 0.12 \mathrm{a}-\mathrm{c} \\
1.41 \pm 0.13 \mathrm{a} \\
1.42 \pm 0.14 \mathrm{a}\end{array}$ & $\begin{array}{c}2.36 \pm 0.08 \mathrm{ef} \\
2.40 \pm 0.08 \mathrm{ef} \\
2.36 \pm 0.07 \mathrm{ef} \\
2.32 \pm 0.09 \mathrm{f}\end{array}$ \\
\hline Moderate water stress & $\begin{array}{l}\text { Direct-seeding } \\
\text { Transplanting }\end{array}$ & $\begin{array}{l}+ \\
- \\
+ \\
-\end{array}$ & $\begin{array}{c}80.7 \pm 4.1 \mathrm{a} \\
0.0 \pm 0.0 \mathrm{e} \\
81.6 \pm 4.3 \mathrm{a} \\
0.0 \pm 0.0 \mathrm{e}\end{array}$ & $\begin{array}{c}12.13 \pm 0.12 \mathrm{e} \\
11.73 \pm 0.09 \mathrm{f} \\
14.00 \pm 0.25 \mathrm{ab} \\
13.63 \pm 0.14 \mathrm{c}\end{array}$ & $\begin{array}{c}6.13 \pm 0.21 \mathrm{a}-\mathrm{c} \\
5.80 \pm 0.10 \mathrm{~cd} \\
6.43 \pm 0.24 \mathrm{a} \\
5.83 \pm 0.11 \mathrm{~d}\end{array}$ & $\begin{array}{l}1.25 \pm 0.10 \mathrm{a}-\mathrm{c} \\
1.24 \pm 0.13 \mathrm{a}-\mathrm{c} \\
1.31 \pm 0.11 \mathrm{a}-\mathrm{c} \\
1.29 \pm 0.12 \mathrm{a}-\mathrm{c}\end{array}$ & $\begin{array}{c}2.88 \pm 0.13 \mathrm{a} \\
2.98 \pm 0.11 \mathrm{a} \\
2.58 \pm 0.10 \mathrm{c}-\mathrm{e} \\
2.64 \pm 0.07 \mathrm{~b}-\mathrm{d}\end{array}$ \\
\hline Sever water stress & $\begin{array}{l}\text { Direct-seeding } \\
\text { Transplanting }\end{array}$ & $\begin{array}{l}+ \\
- \\
+ \\
-\end{array}$ & $\begin{array}{c}45.6 \pm 2.2 \mathrm{~d} \\
0.0 \pm 0.0 \mathrm{e} \\
53 \pm 2.4 \mathrm{c} \\
0.0 \pm 0.0 \mathrm{e}\end{array}$ & $\begin{array}{l}10.03 \pm 0.10 \mathrm{~h} \\
11.70 \pm 0.10 \mathrm{f} \\
12.16 \pm 0.11 \mathrm{e} \\
10.66 \pm 0.11 \mathrm{~g}\end{array}$ & $\begin{array}{c}5.40 \pm 0.11 \mathrm{ef} \\
5.20 \pm 0.10 \mathrm{f} \\
4.60 \pm 0.14 \mathrm{e} \\
5.56 \pm 0.16 \mathrm{e}\end{array}$ & $\begin{array}{l}0.7 \pm 0.08 \mathrm{~d} \\
1.07 \pm 0.09 \mathrm{c} \\
1.1 \pm 0.11 \mathrm{bc} \\
1.09 \pm 0.10 \mathrm{c}\end{array}$ & $\begin{array}{l}2.83 \pm 0.10 \mathrm{ab} \\
2.79 \pm 0.15 \mathrm{a}-\mathrm{c} \\
2.55 \pm 0.09 \mathrm{~d}-\mathrm{f} \\
2.75 \pm 0.09 \mathrm{a}-\mathrm{d}\end{array}$ \\
\hline \multicolumn{8}{|l|}{ Significance } \\
\hline Water stress (W) & & & $* *$ & $* *$ & $* *$ & $* *$ & $* *$ \\
\hline Cultivation method (C) & & & ns & $* *$ & $* *$ & $*$ & $* *$ \\
\hline Inoculation (I) & & & $* *$ & $* *$ & $* *$ & ns & ns \\
\hline $\mathrm{W}^{*} \mathrm{c}$ & & & ns & $*$ & ns & ns & ns \\
\hline $\mathrm{W}^{*} \mathrm{i}$ & & & $* *$ & ns & $*$ & ns & ns \\
\hline $\mathrm{C}^{*} \mathrm{i}$ & & & ns & ns & ns & ns & ns \\
\hline $\mathrm{W}^{*} \mathrm{c}^{* \mathrm{i}}$ & & & ns & ns & ns & ns & ns \\
\hline
\end{tabular}

Data are means of three replications \pm SD. Values within columns in same substrate followed by same letter are not significantly according to Duncan multiple range test at the $p \leq 0.05$ level. Effects of factors according to ANOVA: ns - non-significant effect, ${ }^{*} \mathrm{p} \leq 0.05,{ }^{* *} \mathrm{p} \leq 0.05$. 


\section{Plant nutrient uptake}

The shoot $\mathrm{N}$ content was significantly affected by water stress and cultivation method (Table $3, \mathrm{P} \leq 0.01$ ). Severe water stress significantly decreased the shoot $\mathrm{N}$ content (Table 3 ). Besides, the $\mathrm{N}$ concentration in transplanting plant was higher than that in direct seeding plants (Table 3). In stress conditions, AMF inoculation improved $\mathrm{N}$ uptake. In direct seeding plants under severe stress, AMF inoculation significantly increased the $\mathrm{N}$ content by $17 \%$ in comparison with uninoculated plants (Table 3). Shoot P content was significantly influenced by water stress, AMF inoculation, the interaction of water stress and cultivation method, the interaction of cultivation method and inoculation and also the triple interaction of water stress, AMF inoculation, and cultivation method (Table 3, $\mathrm{P} \leq 0.01$ ). In direct seeding, the highest $\mathrm{P}$ content was observed in moderate stress and uninoculated plants $(0.29 \pm$ $0.009 \%)$. In contrast, in transplanting, under moderate and severe water stress, AMF inoculated plants had greater P content compared with uninoculated plants (Table 3 ). The effects of water stress, cultivation method and their interaction were significant on shoot $\mathrm{K}$ content (Table $3, \mathrm{P} \leq 0.01$ ). In uninoculated plants, under well-watered, moderate water stress, and severe water stress conditions, transplanting enhanced the $\mathrm{K}$ content by $25 \%, 19 \%$, and $34 \%$, respectively, compared with direct seeding (Table 3).

\section{Stomatal density and size}

Stomatal density, width and length were significantly influenced by water stress (Table $4, \mathrm{P} \leq 0.0$ ). Under water stress conditions, stomatal density increased, but stomatal size decreased (Table 4). In direct seeding plants inoculated with AMF, severe stress increased stomatal density by $16 \%$ compared with well-waterbed condition. In transplanting and inoculated plants, severe water stress decreased stomatal width and length by $48 \%$ and $37 \%$, respectively, compared with well-watered condition (Table 4, Figure 2).

\section{Discussion}

The present study showed a positive effect of mycorrhizal symbiosis on plant yield, and photosynthesis pigments of maize grown in two cultivation methods (direct seeding and transplanting). The strong responses of AMF in these harsh environments prove the eminent role of AMF to protect maize plants. In our study, plant growth had different responses to different conditions of germination in two cultivation methods. We observed the successful and significant symbiotic associations established between AMF and maize under moderate water stress. Our results revealed that mycorrhizal colonization increased with moderate drought stress and then decreased by severe water stress. Some studies have shown the increase of colonization under water stress conditions. ${ }^{15}$ Under moderate water stress, AMF developments improved the plant situation via lighter compaction, and desirable pore structure and soil aeration. ${ }^{15}$ In contrast, most experiments indicated that water stress reduced the colonization in different plant species. ${ }^{16}$ The conflicting findings are originated from the responses of AMF isolates to various substrates and the reaction of plants under water stress. ${ }^{17}$ Soil moisture may have different impacts on AMF spore germination and thus root colonization. Furthermore, water stress modifies the performance of root system, which subsequently changed the colonization quality and AMF structures. Transplanting had more AMF colonization in respect to direct seeding. The date of maize cultivation in Iran, especially in semiarid areas such as Karaj, is at the end of spring, enduring the environmental problems induced by increased temperature and lack of rainfall. Therefore, in this situation, the seedlings are more capable in connection with AMF and tolerate the adverse effects of harsh conditions. ${ }^{18}$

Chlorophyll is indispensable for plant photosynthesis by enabling plants to get energy from the light. ${ }^{19}$ Previous studies

Table 3. Effect of Glomus mosae on shoot nutrients uptake in direct seeding and transplanting maize under water stress.

\begin{tabular}{|c|c|c|c|c|c|}
\hline Water stress & Cultivation method & Inoculation & $\mathbf{N}(\%)$ & $P(\%)$ & K $(\%)$ \\
\hline Well-watered condition & $\begin{array}{c}\text { Seeding } \\
\text { Transplanting }\end{array}$ & $\begin{array}{l}+ \\
- \\
+ \\
-\end{array}$ & $\begin{array}{c}3.16 \pm 0.17 \mathrm{~cd} \\
3.26 \pm 0.19 \mathrm{c} \\
3.56 \pm 0.22 \mathrm{ab} \\
3.73 \pm 0.25 \mathrm{a}\end{array}$ & $\begin{array}{c}0.24 \pm 0.008 \mathrm{~cd} \\
0.27 \pm 0.008 \mathrm{~b} \\
0.24 \pm 0.009 \mathrm{~cd} \\
0.26 \pm 0.009 \mathrm{bc}\end{array}$ & $\begin{array}{c}2.13 \pm 0.15 c \\
2.16 \pm 0.15 c \\
2.66 \pm 0.18 \mathrm{ab} \\
2.76 \pm 0.19 \mathrm{a}\end{array}$ \\
\hline Moderate water stress & $\begin{array}{c}\text { Seeding } \\
\text { Transplanting }\end{array}$ & $\begin{array}{l}+ \\
- \\
+ \\
-\end{array}$ & $\begin{array}{c}2.96 \pm 0.15 \mathrm{~d} \\
2.70 \pm 0.13 \mathrm{e} \\
3.33 \pm 0.19 \mathrm{bc} \\
3.36 \pm 0.20 \mathrm{bc}\end{array}$ & $\begin{array}{c}0.27 \pm 0.007 \mathrm{~b} \\
0.29 \pm 0.009 \mathrm{a} \\
0.24 \pm 0.008 \mathrm{~cd} \\
0.21 \pm 0.008 \mathrm{e}\end{array}$ & $\begin{array}{c}2.20 \pm 0.16 c \\
2.16 \pm 0.16 c \\
2.63 \pm 0.18 a b \\
2.50 \pm 0.19 b\end{array}$ \\
\hline Severe water stress & $\begin{array}{c}\text { Seeding } \\
\text { Transplanting }\end{array}$ & $\begin{array}{l}+ \\
- \\
+ \\
-\end{array}$ & $\begin{array}{c}1.53 \pm 0.11 \mathrm{fg} \\
1.30 \pm 0.09 \mathrm{~g} \\
1.63 \pm 0.14 \mathrm{f} \\
1.50 \pm 0.11 \mathrm{fg}\end{array}$ & $\begin{array}{l}0.14 \pm 0.007 \mathrm{f} \\
0.17 \pm 0.008 \mathrm{f} \\
0.20 \pm 0.007 \mathrm{e} \\
0.17 \pm 0.007 \mathrm{f}\end{array}$ & $\begin{array}{l}0.97 \pm 0.11 \mathrm{e} \\
0.97 \pm 0.10 \mathrm{e} \\
1.30 \pm 0.11 \mathrm{~d} \\
1.20 \pm 0.13 \mathrm{~d}\end{array}$ \\
\hline \multicolumn{6}{|l|}{ Significance } \\
\hline Water stress (W) & & & $* *$ & $* *$ & $* *$ \\
\hline Cultivation method (C) & & & $* *$ & ns & $* *$ \\
\hline Inoculation (I) & & & ns & $* *$ & ns \\
\hline$W^{*} \mathrm{C}$ & & & $*$ & $* *$ & $*$ \\
\hline $\mathrm{W}^{*} \mathrm{i}$ & & & $*$ & ns & ns \\
\hline $\mathrm{C}^{*} \mathrm{i}$ & & & ns & $* *$ & ns \\
\hline $\mathrm{W}^{*} \mathrm{c}^{*} \mathrm{i}$ & & & ns & $* *$ & ns \\
\hline
\end{tabular}

Data are means of three replications \pm SD. Values within columns in same substrate followed by same letter are not significantly according to Duncan multiple range test at the $p \leq 0.05$ level. Effects of factors according to ANOVA: ns - non-significant effect, ${ }^{*} \mathrm{p} \leq 0.05,{ }^{* *} \mathrm{p} \leq 0.05$. 
Table 4. Effect of Glomus mosae on stomatal properties and trichomes in direct seeding and transplanting maize under water stress; Stomatal Density (SD), Stomatal Width (SW), Stomatal Length (SL), Unicellular Conical Trichomes (UCT).

\begin{tabular}{|c|c|c|c|c|c|c|}
\hline Water stress & Cultivation method & Inoculation & SD (number $/ \mathrm{mm}^{2}$ ) & SW ( $\mu \mathrm{m})$ & SL( $(\mu \mathrm{m})$ & UCT (number $/ \mathrm{mm}^{2}$ ) \\
\hline Well water condition & $\begin{array}{c}\text { Seeding } \\
\text { Transplanting }\end{array}$ & $\begin{array}{l}+ \\
- \\
+ \\
-\end{array}$ & $\begin{array}{l}74.66 \pm 1.54 \mathrm{c} \\
75.00 \pm 1.55 \mathrm{c} \\
75.00 \pm 1.45 \mathrm{c} \\
75.00 \pm 1.67 \mathrm{c}\end{array}$ & $\begin{array}{l}16.00 \pm 1.26 \mathrm{a} \\
16.66 \pm 1.34 \mathrm{a} \\
16.33 \pm 1.43 \mathrm{a} \\
16.00 \pm 1.32 \mathrm{a}\end{array}$ & $\begin{array}{c}36.00 \pm 2.18 \mathrm{a} \\
35.00 \pm 1.88 \mathrm{ab} \\
35.33 \pm 1.85 \mathrm{ab} \\
35.00 \pm 2.07 \mathrm{ab}\end{array}$ & $\begin{array}{c}55.00 \pm 1.85 b c \\
54.66 \pm 1.76 b c \\
53.00 \pm 1.80 c \\
56.00 \pm 1.85 b c\end{array}$ \\
\hline Moderate water stress & $\begin{array}{c}\text { Seeding } \\
\text { Transplanting }\end{array}$ & $\begin{array}{l}+ \\
- \\
+ \\
-\end{array}$ & $\begin{array}{l}80.00 \pm 1.82 \mathrm{~b} \\
79.66 \pm 1.88 \mathrm{~b} \\
79.00 \pm 1.85 \mathrm{~b} \\
80.00 \pm 1.78 \mathrm{~b}\end{array}$ & $\begin{array}{l}15.00 \pm 1.31 \mathrm{a} \\
14.66 \pm 1.22 \mathrm{a} \\
16.00 \pm 1.25 \mathrm{a} \\
15.33 \pm 1.24 \mathrm{a}\end{array}$ & $\begin{array}{c}33.00 \pm 1.77 \mathrm{~b} \\
33.00 \pm 1.83 \mathrm{~b} \\
33.00 \pm 1.75 \mathrm{~b} \\
34.00 \pm 1.67 \mathrm{ab}\end{array}$ & $\begin{array}{l}58.33 \pm 2.55 b \\
57.66 \pm 2.34 b \\
57.00 \pm 2.55 b \\
57.00 \pm 2.47 b\end{array}$ \\
\hline Sever water stress & $\begin{array}{c}\text { Seeding } \\
\text { Transplanting }\end{array}$ & $\begin{array}{l}+ \\
- \\
+ \\
-\end{array}$ & $\begin{array}{l}87.00 \pm 1.87 \mathrm{a} \\
86.66 \pm 1.92 \mathrm{a} \\
87.33 \pm 1.85 \mathrm{a} \\
85.66 \pm 1.82 \mathrm{a}\end{array}$ & $\begin{array}{l}10.33 \pm 1.18 b \\
11.00 \pm 1.15 b \\
11.00 \pm 1.22 b \\
11.33 \pm 1.19 b\end{array}$ & $\begin{array}{l}26.33 \pm 1.55 c \\
26.00 \pm 1.48 c \\
25.66 \pm 1.53 c \\
26.00 \pm 1.62 c\end{array}$ & $\begin{array}{l}62.00 \pm 2.55 \mathrm{a} \\
61.33 \pm 2.45 \mathrm{a} \\
62.33 \pm 2.74 \mathrm{a} \\
62.33 \pm 2.61 \mathrm{a}\end{array}$ \\
\hline \multicolumn{7}{|l|}{ Significance } \\
\hline Water stress (W) & & & $* *$ & $* *$ & $* *$ & $* *$ \\
\hline Cultivation method (C) & & & ns & ns & ns & ns \\
\hline Inoculation (I) & & & ns & ns & ns & ns \\
\hline $\mathrm{W}^{*} \mathrm{c}$ & & & ns & ns & ns & ns \\
\hline $\mathrm{W}^{*} \mathrm{i}$ & & & ns & ns & ns & ns \\
\hline $\mathrm{C}^{*} \mathrm{i}$ & & & ns & ns & ns & ns \\
\hline $\mathrm{W}^{*} \mathrm{c}^{*} \mathrm{i}$ & & & ns & ns & ns & ns \\
\hline
\end{tabular}

Data are means of three replications \pm SD. Values within columns in same substrate followed by same letter are not significantly according to Duncan multiple range test at the $p \leq 0.05$ level. Effects of factors according to ANOVA: ns - non-significant effect, ${ }^{*} \mathrm{p} \leq 0.05,{ }^{* *} \mathrm{p} \leq 0.05$.
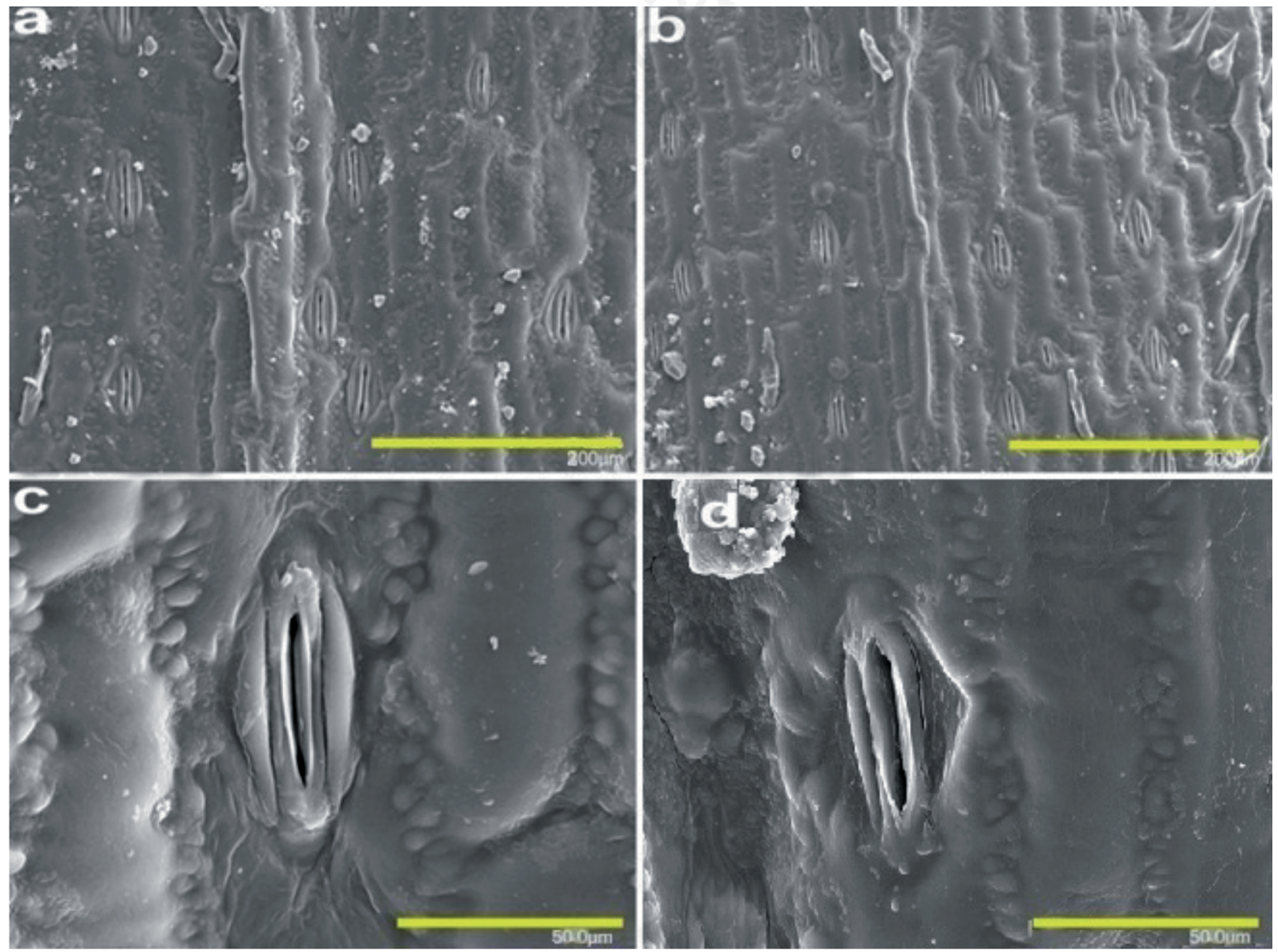

Figure 2. Stomatal density and size in well water condition (a, c) and sever water stress (b, d). 
have shown that the chlorophyll contents significantly decreased under water stress conditions. ${ }^{19,20}$ Our study revealed that AM fungi enhanced the chlorophyll content in maize leaves under water stress condition, which is in agreement with previous works. ${ }^{21,22}$ The increase of chlorophyll content might be related to the improvement in element uptake particularly phosphorus (P) and magnesium $(\mathrm{Mg})$ occurred by AMFinoculation. ${ }^{20}$ High chlorophyll content described that AMF increases the synthesis rate of chlorophyll and improves leaf photosynthesis under water stress condition .The enhancement in chlorophyll content and gas exchange reveal that carbon $(C)$ fixation during the photosynthesis increased by AMF application. It stimulates the AMF growth and the plant photosynthetic rate due to the mutual C-P relationship between AMF and the host plants. ${ }^{19}$ Furthermore, the present results suggest that AMF might decrease the collapse of the leaf cellular structure imposed by water stress.

Our study showed that drought stress decreased the nutrient uptake by plants, which is similar to the results reported by Deng et al. ${ }^{23}$ Mycorrhizal symbiosis can improve plant nutrition, which is mainly considered as an eminent drought tolerance mechanism. ${ }^{23}$ Under severe water stress, we observed an increase of $\mathrm{P}$ content in inoculated plants compared with uninoculated ones. Hijikata et al. ${ }^{24}$ noted that the activity of high-affinity $\mathrm{P}$ transporters on the plasma membrane of extraradical hyphae is the main agent in increasing water stress tolerance in plants. On the other hand, transplanting had more nutrients content compared to direct seeding. It can be due to the fact that seedlings of transplanting method can tolerate more environmental variations and uptake more essential nutrients for a desirable growth. ${ }^{24}$

Stomata are a special gate of gas exchange between atmosphere and plant. They might be influenced by many environmental stresses induced by salinity, temperature, $\mathrm{CO}_{2}$ concentration, and water deficit. ${ }^{25}$ We observed an increase of stomatal density and decrease of stomatal size under water stress condition. Photosynthesis restriction is imposed by both stomatal and nonstomatal impacts under water stress. ${ }^{14}$ Previous reports revealed different behavior of stomatal properties according to water stress and plant species. Several studies have indicated that the stomatal density was enhanced under water stress conditions, ${ }^{26-28}$ while the number of stomata per leaf was reduced. ${ }^{29} \mathrm{Xu}$ and $\mathrm{Zhou}^{30}$ found an increase in stomatal density under water stress, which is in line with our study. In some cases, leaf stomatal size was dwindled with water stress, which is consistent with our study. ${ }^{29,30}$ However, Zhang et al. ${ }^{31}$ demonstrated that stomatal length increased under water stress, whereas its width decreased. Under water stress condition, the negative correlation between stomatal density and stomatal length was observed in leaves of Platanusacerifolia. ${ }^{31}$ Nevertheless, distinguished reactions of abiotic factors on stomatal size might be due to the plant species or varieties. Water deficit may initially inhibit leaf growth and development, dwindling leaf area. ${ }^{32}$ Stomatal density is sharply associated with leaf development, and also the response of cell number and size to water stress depends on the leaf development period. ${ }^{33}$

\section{Conclusions}

This experiment clarified the advantages of transplanting compared with direct seeding of maize under different water regimes using AMF. It showed that water stress decreased the biological and kernel yield of maize. However, we can mitigate the damages induced by severe water stress with application of AMF and trans- planting method. Although water stress altered stomatal properties and UTC, these features remained with no change by cultivation method and AMF application. Finally, the present study suggests the transplanting method with AMF application to cope with drought effects on maize.

\section{References}

1. Ruiz-Lozano JM, Aroca R, Zamarreño ÁM, et al. Arbuscular mycorrhizal symbiosis induces strigolactone biosynthesis under drought and improves drought tolerance in lettuce and tomato. Plant Cell Environ 2016;39:441-52.

2. Golldack D, Li C, Mohan H, Probst N. Tolerance to drought and salt stress in plants: unraveling the signaling networks. Front Plant Sci 2014;5:151-8.

3. Farooq, M, Wahid, A, Kobayashi, N, et al. Plant drought stress: effects, mechanisms and management. In Sustain Agr 2009;153-88. Springer, Dordrecht.

4. Grümberg, BC, Urcelay, C, Shroeder, MA, et al. The role of inoculum identity in drought stress mitigation by arbuscular mycorrhizal fungi in soybean. Biol Fert Soil 2015;51:1-10.

5. Ortiz N, Armada E, Duque E, et al. Contribution of arbuscular mycorrhizal fungi and/or bacteria to enhancing plant drought tolerance under natural soil conditions: effectiveness of autochthonous or allochthonous strains. J Plant physiol 2015;174:87-96.

6. Lampayan RM, Faronilo JE, Tuong TP, et al. Effects of seedbed management and delayed transplanting of rice seedlings on crop performance, grain yield, and water productivity. Field Crop Res 2015;183:303-14.

7. Augé RM, Toler HD, Saxton AM. Arbuscular mycorrhizal symbiosis alters stomatal conductance of host plants more under drought than under amply watered conditions: a metaanalysis. Mycorrhiza 2015;25:13-24.

8. Symanczik S, Lehmann MF, Wiemken A, et al. Effects of two contrasted arbuscular mycorrhizal fungal isolates on nutrient uptake by Sorghum bicolor under drought. Mycorrhiza 2018;28:779-85.

9. Birnbaum, SJ, Poole JM, Williamson PS. Reintroduction of star cactus Astrophytumasterias by seed sowing and seedling transplanting, Las Estrellas Preserve, Texas, USA. Cons Evid 2011;8:43-52.

10. Sánchez JM, López-Urrea R, Rubio E, \& Caselles V. Determining water use of sorghum from two-source energy balance and radiometric temperatures. Hydrol Earth System Sci 2011;15:3061-70.

11. Zadworny M, Eissenstat, DM. Contrasting the morphology, anatomy and fungal colonization of new pioneer and fibrous roots. New Phytol 2011;190:213-21.

12. Arnon DI. Copper enzymes in isolated chloroplasts. Polyphenoloxidase in Beta vulgaris. Plant Physiol 1949;24:1-5.

13. Maathuis, FJ. Plant mineral nutrients: Methods and protocols. New Delhi, India: Humana Press: 2013.

14. Khosropour E, Attarod P, Shirvan A, et al. Response of Platanus orientalis leaves to urban pollution by heavy metals. J For Res 2019;30:1437-45.

15. Zhao R, Guo W, Bi N, Guo J. Arbuscular mycorrhizal fungi affect the growth, nutrient uptake and water status of maize (Zeamays L.) grown in two types of coal mine spoils under drought stress. Appl Soil Ecol 2015;88:41-9.

16. El-Mesbahi MN, Azcón R, Ruiz-Lozano JM, Aroca R. Plant 
potassium content modifies the effects of arbuscular mycorrhizal symbiosis on root hydraulic properties in maize plants. Mycorrhiza 2012;22:555-64.

17. Gholamhoseini M, Ghalavand A, Dolatabadian A. Effects of arbuscular mycorrhizal inoculation on growth, yield, nutrient uptake and irrigation water productivity of sunflowers grown under drought stress. Agr Water Manage 2013;117:106-14.

18. Gill G, Humphreys E, Kukal SS, Walia US. Effect of water management on dry seeded and puddled transplanted rice. Part 1: Crop performance. Field Crop Res 2011;120:112-22.

19. Lakra N, Nutan KK, Das P.A nuclear-localized histone-gene binding protein from rice (OsHBP1b) functions in salinity and drought stress tolerance by maintaining chlorophyll content and improving the antioxidant machinery. J Plant Physiol 2015;176:36-46.

20. Shivakrishna P, Reddy KA, Rao DM. Effect of PEG-6000 imposed drought stress on RNA content, relative water content (RWC), and chlorophyll content in peanut leaves and roots. Saudi J Biol Sci 2018;25:285-9.

21. Elhindi KM, El-Din AS, Elgorban AM, 2017, The impact of arbuscular mycorrhizal fungi in mitigating salt-induced adverse effects in sweet basil (Ocimum basilicum L.). Saudi J Biol Sci 24:170-9.

22. Mohammadi M, Modarres-Sanavy SAM, Pirdashti H, et al. Arbuscular mycorrhizae alleviate water deficit stress and improve antioxidant response, more than nitrogen fixing bacteria or chemical fertilizer in the evening primrose. Rhizosphere 2019;9:76-89.

23. Deng M, Li P, Wang Z, et al. Drought and salinization stress induced by stand development alters mineral element cycling in a larch plantation. $J$ Geophys Res Biogeosci 2021;126:e2020JG005906.

24. Hijikata N, Murase M, Tani C. Polyphosphate has a central role in the rapid and massive accumulation of phosphorus in extraradical mycelium of an arbuscular mycorrhizal fungus. New Phytol 2010;186:285-9.

25. Steinthorsdottir M, Vajda, Pole M. Significant transient pCO2 perturbation at the New Zealand Oligocene-Miocene transition recorded by fossil plant stomata. Palaeogeogr Palaeoclimatol Palaeoecol 2019;515:152-61.

26. YangH, Wang G. Leaf stomatal densities and distribution in triticum aestivum under drought and $\mathrm{CO}_{-}(2)$ enrichment. Acta Phytoecol Sinica 2001;25:312-6.

27. Gan Y, Zhou L, Shen ZJ, et al. Stomatal clustering, a new marker for environmental perception and adaptation in terrestrial plants. Bot Stud 2010;51:1-7.

28. Haworth M, Scutt CP, Douthe C, et al. Allocation of the epidermis to stomata relates to stomatal physiological control: stomatal factors involved in the evolutionary diversification of the angiosperms and development of amphistomaty. Environ Exp Bot 2018;151:55-63.

29. Quarrie, SA, Jones HG. Genotypic variation in leaf water potential, stomatal conductance and abscisic acid concentration in spring wheat subjected to artificial drought stress. Ann Bot 1979;44:323-32.

30. Xu Z, Zhou G. Responses of leaf stomatal density to water status and its relationship with photosynthesis in a grass. J Exp Bot 2008;59:3317-25.

31. Zhang H, Wang X, Wang S. A study on stomatal traits of Platanusacerifolia under urban stress. J Fudan University Nat Sci 2004;43:651-6.

32. Comas LH, Trout TJ, DeJonge KC, et al. Water productivity under strategic growth stage-based deficit irrigation in maize. Agr Water Manage2019;212:433-40.

33. Fontana M, Labrecque M, Collin A, Bélanger N. Stomatal distribution patterns change according to leaf development and leaf water status in Salix miyabeana. Plant Growth Regul 2017;81:63-70. 